\title{
Study on Histomorphological Findings in Placenta in Cases of Pregnancy Induced Hypertension
}

\author{
Rekha Kumari ${ }^{\oplus 1}$, Nakul Choudhary ${ }^{\oplus}$, Rashmi Prasad ${ }^{\oplus 3}$ \\ ${ }^{1}$ Assistant Professor, Department of Anatomy, JLNMCH, Bhagalpur, Bihar, India, ${ }^{2}$ Assistant Professor, Department of Anatomy, VIMS, Pawapuri, Nalanda, Bihar, India, \\ ${ }^{3}$ Professor \& Head, Department of Anatomy, VIMS, Pawapuri, Nalanda, Bihar, India.
}

\section{Abstract}

Introduction: PIH is a common condition associated with changes in placenta. It leads to increased perinatal mortality. The present study was conducted to assess the morphological and histopathological changes in placenta in cases of pregnancy induced hypertension. Subjects and Methods: The present comparative study included 49 cases of PIH and 49 normotensive mothers. Clinical details and placental morphology were noted. Results: That the two groups are similar with no significant difference. Placental weight and diameter were similar in PIH and control groups ( $p>0.05$ ). However, placental thickness and number of cotyledons were greater in PIH group ( $p=0.00)$ while placental volume was lower with significant difference $(\mathrm{p}=0.01)$. PIH group showed greater proportion of infarction, calcification, hyalinised area per 10 lpf and intervillous haemorrhage ( $\mathrm{p}=0.00)$. Conclusion: PIH leads to gross and microscopic changes in placental morphology.

Keywords: Comparative Study, Histology, Morphology, Placenta, Pregnancy induced hypertension

Corresponding Author: Nakul Choudhary, Assistant Professor, Department of Anatomy, VIMS, Pawapuri, Nalanda, Bihar, India. E-mail: drnakuldmc95@gmail.com

\section{Introduction}

The human placenta is an intrauterine fusion of fetal and maternal tissues and is the vital organ for maintaining pregnancy and promoting development of the fetus. ${ }^{[1]}$ Hypertensive disorders of pregnancy are common. Along with haemorrhage \& infection, these contribute greatly to maternal $\&$ foetal morbidity $\&$ mortality and complicate $7-10 \%$ of all pregnancies. ${ }^{[2]}$ Pregnancy induced hypertension which includes pre-eclampsia and eclampsia, is responsible for $70 \%$ of the hypertensive disorders of pregnancy. ${ }^{[3]}$

The hypertensive disorders are classified into three clinical types: - 1. Pre-eclampsia, 2. Eclampsia and 3. Gestational Hypertension. Pre-eclampsia is characterized by increase of blood pressure upto140/90 $\mathrm{mm}$ of $\mathrm{Hg}$ recorded on two occasions 6 hours apart with proteinuria $(0.3 \mathrm{gms}$ or more protein in 24 hour collected sample with $1+$ or greater on urine dipstick test) after 20th weeks of gestation involving multiple organ system. It is more common in primigravidae $(10 \%)$ than multigravidae $(5 \%)$. Eclampsia is defined as the pre-eclampsia complicated with convulsions and/or coma. It is a life-threatening condition and usually occurs quite abruptly without any warning. Gestational hypertension is defined as sustained rise of blood pressure to $140 / 90 \mathrm{~mm}$ of $\mathrm{Hg}$ or more on at least two occasions, four or more hours apart beyond 20th week of pregnancy or during the first 24 hours after delivery in a previously normotensive woman. ${ }^{[4]}$

In pregnancy induced hypertension (PIH), pathological changes in the placenta such as infarction, calcifications, diffuse placental thrombosis, inflammatory placental vasculopathy and abnormal trophoblastic proliferation occur. It results in reduced blood flow across placenta and uteroplacental insufficiency. ${ }^{[5]}$ Naeye and Friedman (1979) found that $70 \%$ of excess foetal deaths in women with hypertension are due to placental infarcts. Maternal utero-placental blood flow is decreased in PIH due to maternal vasospasm and causes indirect constriction of foetal stem arteries. Histological findings like cytotrophoblastic cellular proliferation, syncytial knot formation, fibrin plaque formation etc. are more common in placentae of hypertensive mothers. ${ }^{[6]}$

Few studies have been conducted in this area to find the placental morphology and changes during pregnancy induced hypertension. Exploration of these changes will be helpful in providing the insight in the etiopathogenesis. Hence, the present study was conducted.

\section{Aims \& Objectives}


The present study was conducted to assess the morphological and histopathological changes in placenta in cases of pregnancy induced hypertension.

\section{Subjects and Methods}

Study setting: The present study was conducted at the Department of Anatomy, VIMS, Pawapuri, Bihar.

Study Design: The present study was hospital-based crosssectional in nature.

Study period: The study was conducted between September 2018 to December 2018.

Study subjects: The study subjects included two groups. Mothers suffering from PIH were included in the study group while normotensive mothers constituted the control group. Seriously ill patients and those who refused to give consent were excluded.

Sampling: All the mothers suffering from PIH (blood pressure of 140/90 mm of $\mathrm{Hg}$ or more, with or without oedema and/or proteinuria) and reporting to the hospital during the study period were included in the study group. A total of 49 mothers were selected. An equal number of normotensive mothers were selected and these constituted the control group. The mothers in the control group were randomly selected. Seriously ill mothers and those with hypertension prior to pregnancy were excluded.

Data collection procedure: The OBG ward of the institute was visited and study and control groups were recruited in the study. Pre-tested proforma was used for data collection which included questions regarding background information and details of pregnancy. Details regarding PIH were noted in the study group.

The placenta was collected soon after delivery and weight were noted. Placentae were perfused with $10 \%$ formalin through umbilical vessels. This was followed by immersion in a jar containing 10\% formalin for 48 hours. Gross examination of the placentae was done to note the presence of any infarction, calcification and retro placental clots. Tissues were taken and processed for histological observations for light microscopic studies from site near the attachment of umbilical cord, margin and centre of the placenta. Slides were stained with Haematoxylin and Eosin ( $\mathrm{H} \& \mathrm{E})$ to study the histology of placenta. In light microscopic examination of the placental villi were screened for counting of number of syncytial knots per 100 villi, fibrinoid necrosis,intervillous haemorrhage, cytotrophoblastic cellular proliferation and calcification.

Data analysis: Data was entered in Microsoft Excel and analyzed using SPSS software. Percentage, proportions and contingency tables were used for describing the data. $P$ value $<0.05$ was considered as statistically significant.
Ethical consideration \& permission: Approval from Institutional Ethics Committee was obtained. Informed consent was taken from the patients. Confidentiality of records was maintained.

\section{Results}

A total of 98 subjects were included in the present study. [Table 1] shows background characteristics of PIH group and controls. It is seen that the two groups are similar with no significant difference with respect to age and parity $(\mathrm{P}>0.05)$. However, the gestational period was lower in PIH group and the difference was significant $(\mathrm{p}=0.00)$.

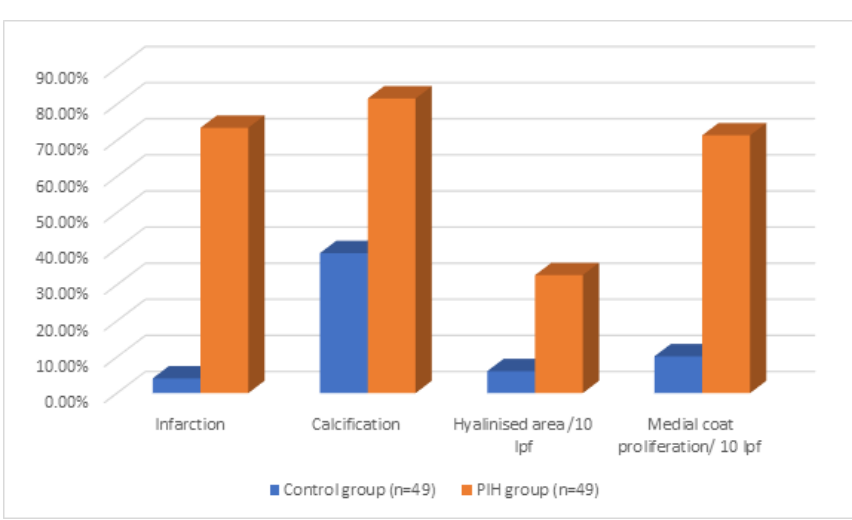

Figure 1: Showing histological changes

Table 1: Comparing background characteristics of PIH group with control

\begin{tabular}{|c|c|c|c|}
\hline Characteristi & $\begin{array}{l}\text { Control } \\
\text { group } \\
(n=49)\end{array}$ & $\begin{array}{l}\text { PIH group } \\
(n=49)\end{array}$ & Significance \\
\hline $\begin{array}{l}\text { Age (in } \\
\text { years) }\end{array}$ & $28.9 \pm 4.2$ & $29.3 \pm 4.1$ & $\begin{array}{l}\mathrm{t}=0.47 \\
\mathrm{p}=0.63\end{array}$ \\
\hline Parity & $2.1 \pm 0.9$ & $2.3 \pm 1.0$ & $\begin{array}{l}\mathrm{t}=1.04 \\
\mathrm{p}=0.30\end{array}$ \\
\hline $\begin{array}{l}\text { Gestational } \\
\text { period }\end{array}$ & $37.8 \pm 1.3$ & $36.9 \pm 0.9$ & $\begin{array}{l}\mathrm{t}=-3.98 \\
\mathrm{p}=0.00\end{array}$ \\
\hline
\end{tabular}

[Table 2] shows placental morphology. Placental weight and diameter were similar in PIH and control groups $(\mathrm{p}>0.05)$. However, placental thickness and number of cotyledons were greater in PIH group $(p=0.00)$ while placental volume was lower with significant difference $(\mathrm{p}=0.01)$.

[Table 3] shows findings of histopathological examination. PIH group showed greater proportion of infarction, calcification, hyalinised area per $10 \mathrm{lpf}$ and intervillous haemorrhage $(\mathrm{p}=0.00)$. There was decreased villous 
Table 2: Showing placental morphology among PIH and control groups

\begin{tabular}{|llll}
\hline $\begin{array}{l}\text { Placental } \\
\text { morphol- } \\
\text { ogy }\end{array}$ & $\begin{array}{l}\text { Control } \\
\text { group }(\mathbf{n = 4 9})\end{array}$ & $\begin{array}{l}\text { PIH group } \\
(\mathbf{n}=\mathbf{4 9})\end{array}$ & Significance \\
\hline Weight & $434.8 \pm 19.1$ & $398.0 \pm 17.6$ & $\begin{array}{l}\mathrm{t}=-9.92, \\
\mathrm{p}=0.00\end{array}$ \\
\hline Diameter & $18.1 \pm 2.1$ & $17.7 \pm 2.3$ & $\begin{array}{l}\mathrm{t}=-0.89, \\
\mathrm{p}=0.37\end{array}$ \\
\hline Thickness & $1.5 \pm 0.4$ & $1.7 \pm 0.3$ & $\begin{array}{l}\mathrm{t}=2.8, \\
\mathrm{p}=0.00\end{array}$ \\
\hline $\begin{array}{l}\text { Volume } \\
\text { of }\end{array}$ & $17.3 \pm 2.4$ & $18.8 \pm 3.1$ & $\begin{array}{l}\mathrm{t}=-2.54, \\
\mathrm{p}=0.01\end{array}$ \\
\hline $\begin{array}{l}\text { No. } \\
\text { cotyledons }\end{array}$ & & $340.1 \pm 89.008$ \\
\hline
\end{tabular}

Table 3: Showinghistopathological findings

\begin{tabular}{|c|c|c|c|}
\hline $\begin{array}{l}\text { Histopatholọ } \\
\text { findings }\end{array}$ & $\begin{array}{l}\text { Control } \\
\text { group } \\
(n=49)\end{array}$ & $\begin{array}{l}\text { PIH group } \\
(n=49)\end{array}$ & Significance \\
\hline Infarction & $4.1 \%$ & $73.5 \%$ & $\begin{array}{l}X 2=49.2 \\
p=0.00\end{array}$ \\
\hline Calcification & $38.8 \%$ & $81.6 \%$ & $\begin{array}{l}X 2=18.5 \\
p=0.00\end{array}$ \\
\hline $\begin{array}{l}\text { Hyalinised } \\
\text { area /10 lpf }\end{array}$ & $6.1 \%$ & $32.7 \%$ & $\begin{array}{l}X 2=10.9 \\
p=0.00\end{array}$ \\
\hline $\begin{array}{l}\text { Medial coat } \\
\text { prolifer- } \\
\text { ation/ } 10 \\
\text { lpf }\end{array}$ & $10.2 \%$ & $71.4 \%$ & $\begin{array}{l}X 2=37.6 \\
p=0.00\end{array}$ \\
\hline $\begin{array}{l}\text { Intervillous } \\
\text { haemor- } \\
\text { rhage }\end{array}$ & $8.2 \%$ & $67.3 \%$ & $\begin{array}{l}X 2=36.0 \\
p=0.00\end{array}$ \\
\hline $\begin{array}{l}\text { Decreased } \\
\text { Villous } \\
\text { Vascularity }\end{array}$ & $2 \%$ & $75.5 \%$ & $\begin{array}{l}X 2=55.2 \\
p=0.00\end{array}$ \\
\hline $\begin{array}{l}\text { Syncytial } \\
\text { knots per } \\
100 \text { villi }\end{array}$ & $25.4 \pm 9.8$ & $67.6 \pm 11.9$ & $\begin{array}{l}\mathrm{t}=19.1 \\
\mathrm{p}=0.00\end{array}$ \\
\hline
\end{tabular}

vascularity in this group $(\mathrm{p}=0.00)$ while number of syncytial knots per 100 villi were more with a significant difference $(p=0.00)$.

\section{Discussion}

Placental condition denotes maternal and foetal well-being and any aberration in placental morphology indicates fetomaternal compromise. PIH is one of the important conditions causing placental abnormalities. The present study explored histomorphological changes in placenta in PIH cases. Many conditions lead to changes in size, weight, thickness etc. of placenta e.g. parity, gestational age, diabetes, hypertension. Hence, the study and control groups were matched as far as possible. ${ }^{[7]}$

A total of 98 subjects were included in the present study. It is seen that the two groups are similar with no significant difference with respect to age and parity $(\mathrm{P}>0.05)$. However, the gestational period was lower in PIH group and the difference was significant $(p=0.00)$. The study by Wubale et al showed that the mean age of participants was 26.46 \pm 2.95 year in normotensive and $25.56 \pm 2.84$ year in preeclamptic mothers. Most of preeclamptic and normotensive mothers were Para 0 and Para 1 respectively. ${ }^{[8]}$ Begumet al also reported that there was no significant difference in maternal age, weight, parity and gestational age among the two study groups. The mean weight of mother in PIH group had higher $(64.1 \pm 8.78)$ than control group $(59.3 \pm 5.08)$. The mean gestational age of the mother in PIH group was lower $(37.55 \pm 1.23)$ than that of control group $(38.1 \pm 1.02){ }^{\text {[9] }}$

Placental weight and diameter were similar in PIH and control groups $(\mathrm{p}>0.05)$. However, placental thickness and number of cotyledons were greater in PIH group $(p=0.00)$ while placental volume was lower with significant difference $(p=0.01)$. In the study done by Motwani et al, mean weight of the placenta was significantly lower in PIH groups (395.00 gms) than in the control group (462.16 gms). ${ }^{[10]}$ similar findings were observed by Wubale et al who found that placental weight was significantly $(\mathrm{p}<0.00001)$ decreased in preeclamptic $(456.20$ \pm 19.13 gram) than normotensive (499.4 \pm 11.89 gram) mothers. Placental diameter and thickness in preeclamptic mothers were $17.66 \pm 1.07$ centimeter and $1.72 \pm 0.11$ centimeter respectively. ${ }^{[8]}$

PIH group showed greater proportion of infarction, calcification, hyalinised area per $10 \mathrm{lpf}$ and intervillous haemorrhage $(p=0.00)$. There was decreased villous vascularity in this group $(p=0.00)$ while number of syncytial knots per 100 villi were more with a significant difference $(\mathrm{p}=0.00)$. Upon gross examination of the placentae, calcification and infarction were more commonly seen in mothers suffering from PIH as also seen by Motwani et al. ${ }^{[10]}$ The calcification is a sign of 'aging' of the placenta that occurs near the end of pregnancy. Due to premature aging in cases of PIH, the amount of nutrition and oxygen reaching the baby is reduces and this worsens the postnatal outcome. Placental infarction of more than $5 \%$ surface area is considered pathological. It is frequently seen in PIH due to thrombotic occlusion of maternal uteroplacental vessels. Salmani et al also found significant number of syncytial knots, fibrinoid necrosis, areas of calcification and hyalinisation and areas of medial coat proliferation of medium sized blood vessels in the hypertensive group, whereas the control 
group showed normal histological features. ${ }^{[7]}$ Similar observations were made by Gore et al. They found that the mean number of syncytial knots was $72.6 \pm 14.8$ in PIH group while it was $29.3 \pm 7.8$ in the control group which was found significant (0.001). It was higher in PIH group compared to the control group. They found higher number of syncytial knots in preeclamptic placenta as compared to the control placenta. There was a statistically significant association between PIH and presence of hyalinised area. ( $\mathrm{p}$ value 0.0003 ). The mean number of cytotrophoblastic proliferation was $16.2 \pm 4.27$ in $\mathrm{PIH}$ group while it was $3.6 \pm 2.57$ in control group.

\section{Conclusion}

It is concluded from the present study that PIH significantly alters placental thickness \& volume and number of cotyledons. The histopathological changes are more prominent which differ significantly from normotensive subjects. Prompt treatment of PIH is needed to prevent the harm to the foetus and the mother.

\section{References}

1. Udainia A, Jain ML. Morphological Study of Placenta in Pregnancy Induced Hypertension With its Clinical Relevance. J Anat Soc India. 2001;50:24-31.

2. Hauth JC, Ewell MG, Levine RJ, Esterlitz JR, Sibai B, Curet LB. Pregnancy outcomes in healthy nulliparas who developed hypertension. Calcium for Preeclampsia Prevention Study Group. Obstet Gynecol. 2000;95:24-32. Available from: https://doi.org/10.1016/s0029-7844(99)00462-7.

3. Barton JR, O'Brien JM, Bergauer NK, Jacques DL, Sibai BM. Mild gestational hypertension remote from term: Progression and outcome. Am J Obstet Gynecol. 2001;184(5):979-983. Available from: https://dx.doi.org/10.1067/mob.2001.112905.
4. Gynaecology TO; 2020. Available from: https://www.flipkart. com/textbook-of-gynaecology/p/itmdf8qzjfhe6x8q.

5. Ahmed M, Daver RG. Study of placental changes in pregnancy induced hypertension. Int J Reprod. 2016;2:524-531.

6. Naeye RL, Friedman EA. Causes of perinatal death associated with gestational hypertension and proteinuria. Am J Obstet Gynecol. 1979;133(1):8-10. Available from: https://dx.doi. org/10.1016/0002-9378(79)90402-2.

7. Salmani D, Purushothaman S, Somashekara S, Gnanagurudasan E, Sumangaladevi K, Harikishan R, et al. Study of structural changes in placenta in pregnancy-induced hypertension. J Nat Sci Biol Med. 2014;5(2):352-352. Available from: https://dx.doi.org/10.4103/0976-9668.136182.

8. Wubale Y. Gross morphological study of placenta in preeclampsia. Anat J Afr. 2017;6:977-981.

9. Begum N, Ferdousi R. Study of Gross Anatomy of Human Placenta in Pregnancy Induced Hypertension. J Armed Forces Med Coll. 2015;10(2):55-61. Available from: https://dx.doi. org/10.3329/jafmc.v10i2.25923.

10. Motwani R, Sontakke Y, Goyal M. Effects of Pregnancy Induced Hypertension on Human Placenta . J Evol Med Dent Sci. 2013;2(33):6275-6282. Available from: https://dx.doi.org/ $10.14260 /$ jemds $/ 1130$.

Copyright: (C) the author(s), 2020. It is an open-access article distributed under the terms of the Creative Commons Attribution License (CC BY 4.0), which permits authors to retain ownership of the copyright for their content, and allow anyone to download, reuse, reprint, modify, distribute and/or copy the content as long as the original authors and source are cited.

How to cite this article: Kumari R, Choudhary N, Prasad R. Study on Histomorphological Findings in Placenta in Cases of Pregnancy Induced Hypertension. Acad. Anat. Int. 2020;6(2):5659.

DOI: dx.doi.org/10.21276/aanat.2020.6.2.12

Source of Support: Nil, Conflict of Interest: None declared. 